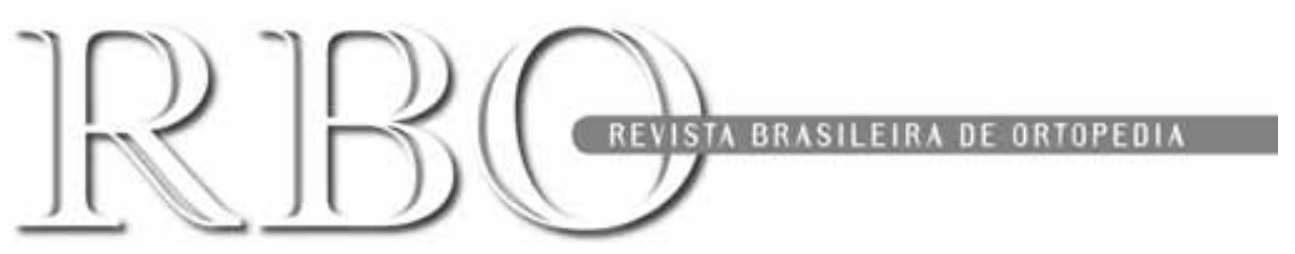

\title{
Editorial
}

\section{Personalidade editorial}

O acesso à informação é um dos maiores avanços de nosso tempo. Ter a possibilidade de obter em tempo real notícias e imagens de fatos que ocorrem naquele instante tornou o mundo menor e as pessoas mais próximas. Os sites de busca são outro avanço na internet, que em segundos disponibilizam informações sobre quase tudo.

o mesmo impacto positivo da agilidade, da liberdade e do anonimato que a internet trouxe tem como lado negativo a falta de personalidade do sistema.

No sistema convencional de noticias há a responsabilidade da informação cobrada de forma legal e mesmo moral; os órgãos de comunicação têm compromissos que os obrigam a ter uma personalidade editorial.

No campo da notícia impressa talvez essa personalidade seja mais marcante, pela própria característica documental da palavra escrita.

No campo da editoração científica temos revistas que praticamente só são publicadas on-line, existindo de forma física em apenas poucos exemplares. São revistas com títulos de fácil acesso, disponibilizadas em sites de busca especializados em publicações médicas.

A inegável facilidade que os sistemas de busca trouxeram deve limitar-se apenas ao fato de localizar e relacionar as publicações; caberá ao leitor analisar a personalidade editorial da publicação escolhida.

A personalidade editorial de uma revista científica, que define sua qualidade, é dada pelo seu corpo de editores, pela sua tradição e pelas entidades às quais está ligada e não pela exposição a este ou aquele site de busca.

A RBO neste número publica o nome de todos os editores que vêm estabelecendo sua linha editorial e auxiliando os autores a ter a qualidade que a define como uma das revistas médicas mais lidas.

$\mathrm{Na}$ organização de todo o grupo que reúne os editores de nossa revista tivemos que obedecer a certos princípios que normatizam essa matéria frente aos órgãos de indexação e os estatutos da SBOT.

São vários os níveis de atuação. Temos um conselho editorial que tem sua formação regida por estatuto e é composto por sete membros escolhidos diretamente pelos presidentes da SBOT, que indicam dois membros em sua gestão. Esses membros ficam por três anos nessa função. Participam da definição da política editorial e administrativa da RBO e elegem o editor-chefe (o sétimo membro), que terá mandato de seis anos, podendo ser reconduzido por uma vez.

$\mathrm{O}$ conselho editorial elege o corpo editorial, que também é definido por estatuto e é composto por 33 membros. Na composição do corpo editorial deve ter-se o cuidado de escolher membros representativos de todo o país e dos serviços mais importantes, por exigência dos sistemas de indexação. 0 corpo editorial pode ser renovado anualmente.

O conselho editorial, o corpo editorial e o editor-chefe convidam os membros do corpo de consultores baseados na produção científica do consultor. Os consultores podem não ser ortopedistas e são solicitados sempre que o editorchefe julgar necessário.

Em nossa gestão criamos os editores de área, que são especialistas ligados a área específica de conhecimento e indicados pelos comitês de especialidade. Sua substituição é orientada pela diretoria do comitê correspondente.

Para julgamento e orientação do editor, trabalhos são enviados para dois ou três membros do corpo de editores. 0 critério é a familiaridade dos editores com o assunto do trabalho; não há, portanto, nenhuma hierarquia entre os colaboradores da RBO. Hoje, o envio de trabalhos é on-line; portanto, as respostas são mais rápidas e o diálogo (embora sigiloso) entre editor e autor é mais ágil.

Temos 104 editores em todo o país, que conhecem profundamente toda a ortopedia brasileira e podem conferir a seriedade e a personalidade necessárias para manter a RBO dentro de seus padrões atuais. Continuamos no processo de indexação em sistemas internacionais que permitirá a exposição da RBO em sites de busca, pois não podemos estar alheios aos avanços da atividade de editoração científica, mas nunca nos afastaremos de nossa personalidade editorial.

Gilberto Luis Camanho Editor-chefe 